\title{
Interpreting and responding to the Johannine feeding narrative: An empirical study in the SIFT hermeneutical method amongst Anglican ministry training candidates
}

\author{
Author: \\ Leslie J. Francis ${ }^{1,2}$ \\ Affiliations: \\ ${ }^{1}$ Warwick Religions and \\ Education Research Unit, \\ University of Warwick, \\ United Kingdom \\ ${ }^{2}$ Department of New \\ Testament Studies, University \\ of Pretoria, South Africa \\ Note: \\ Prof. Dr Leslie J. Francis is \\ participating as a research \\ associate of Prof. Dr Andries \\ G. van Aarde, Honorary \\ Professor at the Faculty of \\ Theology of the University of
} Pretoria, South Africa.

\section{Correspondence to:}

Leslie Francis

Email:

leslie.francis@warwick.ac.uk

\section{Postal address:}

Warwick Religions and

Education Research Unit,

Institute of Education, The

University of Warwick

Coventry CV4 7AL, United

Kingdom

\section{Dates:}

Received: 19 Dec. 2011

Accepted: 05 Feb. 2012

Published: 17 Aug. 2012

How to cite this article: Francis, L.J., 2012,

'Interpreting and responding to the Johannine feeding narrative: An empirical study in the SIFT hermeneutical method amongst Anglican ministry training candidates' HTS Teologiese Studies/ Theological Studies 68(1), Art. \#1205, 9 pages. http:// dx.doi.org/10.4102/hts v68i1.1205

C 2012. The Authors Licensee: AOSIS OpenJournals. This work is licensed under the Creative Commons Attribution License.
Drawing on Jungian psychological type theory, the SIFT method of biblical hermeneutics and liturgical preaching maintains that different psychological type preferences are associated with distinctive readings of scripture. In the present study this theory was tested amongst two groups of ministry training candidates (a total of 26 participants) who were located within working groups according to their psychological type preferences, and invited to reflect on the Johannine feeding narrative (Jn 6:4-22), and to document their discussion. Analysis of these data provided empirical support for the theory underpinning the SIFT method.

\section{Introduction}

The SIFT method of biblical hermeneutics and liturgical preaching belongs to the broad category of hermeneutical approaches that takes reader perspective seriously and recognises the importance of context. What is so distinctive about the SIFT method is that context is not defined by sociological categories (as in feminist, liberation or Black reader perspectives) but by psychological categories. The psychological categories that define reader perspective within the SIFT approach are derived from the broad field of psychological type theory.

Psychological type theory has its origins in the pioneering and innovative thinking of Carl Jung (1971) and has been developed, modified and extended through a series of self-report type indicators, including the Myers-Brigg Type Indicator (Myers \& McCaulley 1985), the Keirsey Temperament Sorter (Keirsey \& Bates 1978) and the Francis Psychological Type Scales (Francis 2005). The aspect of psychological type theory directly relevant to the SIFT method of biblical hermeneutics and liturgical preaching concerns the identification of the four key psychological functions that Jung characterised as sensing (S), intuition (I), feeling (F) and thinking (T). Within Jung's model, sensing and intuition are defined as two contrasting expressions of the perceiving process, and thinking and feeling are defined as two contrasting expressions of the judging process.

For Jung, the two perceiving functions are concerned with the way in which people perceive information. On the one hand, sensing types focus on the realities of a situation as perceived by the senses. They tend to focus on specific details, rather than on the overall picture. They are concerned with the actual, the real, and the practical, and they tend to be down to earth and matter of fact. On the other hand, intuitive types focus on the possibilities of a situation, perceiving meanings and relationships. They may feel that perception by the senses is not as valuable as information gained when indirect associations and concepts impact on their perception. They focus on the overall picture, rather than on specific facts and data.

For Jung, the two judging functions are concerned with the processes by which people make decisions and judgements. On the one hand, thinking types make judgements based on objective, impersonal logic. They value integrity and justice. They are known for their truthfulness and for their desire for fairness. They consider conforming to principles to be of more importance than cultivating harmony. On the other hand, feeling types make judgements based on subjective, personal values. They value compassion and mercy. They are known for their tactfulness, for their desire for peace and for their empathic capacity. They are more concerned to promote harmony, than to adhere to abstract principles.

Jung's view is that each individual develops one of the perceiving functions (sensing or intuition) at the expense of the other, and one of the judging functions (feeling or thinking) at the expense of the other. Moreover, for each individual either the preferred perceiving function or the preferred judging function takes preference over the other, leading to the emergence of one 
dominant function which shapes the individual's dominant approach to life. Dominant sensing shapes the practical person. Dominant intuition shapes the imaginative person. Dominant feeling shapes the humane person. Dominant thinking shapes the analytic person. According to Jungian type theory, the function paired with the dominant function is known as the 'inferior function'. It is here that individuals experience most difficulty. Thus dominant sensers may struggle with intuition; dominant intuitives may struggle with sensing; dominant feelers may struggle with thinking; and dominant thinkers may struggle with feeling.

Applying psychological type theory to the fields of biblical hermeneutics and liturgical preaching, the SIFT method had its origins in Francis' (1997) study of Mark's Gospel, was developed and extended in the three volume commentary on the principal Sunday gospel readings proposed in the Revised Common Lectionary by Francis and Atkins (2000, 2001, 2002). This was further analysed and discussed by Francis and Village (2008). In essence, the SIFT method of biblical hermeneutics and liturgical preaching systematically addresses to each passage of scripture the four sets of questions that follow, posed by the four psychological functions of sensing (S), intuition (I), feeling (F), and thinking (T). The two perceiving functions (sensing and intuition) are applied first, as the perceiving process is concerned with gathering information and ideas. The two judging functions (feeling and thinking) are applied second, because the judging process is concerned with evaluating information and ideas.

The first step in the SIFT method is to address the sensing perspective. It is the sensing perspective which gets to grip with the text itself and which gives proper attention to the details of the passage, and may wish to draw on insights of historical methods of biblical scholarship in order to draw in 'facts' from other parts of the Bible. The first set of questions asks, 'How does this passage speak to the sensing function? What are the facts and details? What is there to see, to hear, to touch, to smell, and to taste?'

The SIFT method maintains that when sensing types hear a passage of scripture, they want to savour all the detail of the text and may become fascinated by descriptions that appeal to their senses. They tend to start from a fairly literal interest in what is being said. Sensing types may want to find out all they can about the passage and about the facts that stand behind the passage. They welcome preachers who lead them into the passage by repeating the story and by giving them time to observe and to appreciate the details. Sensing types quickly lose the thread if they are bombarded with too many possibilities too quickly.

The second step in the SIFT method is to address the intuitive perspective. It is the intuitive perspective which relates the biblical text to wider issues and concerns. The second set of questions asks, 'How does this passage speak to the intuitive function? What is there to speak to the imagination, to forge links with current situations, to illuminate issues in our lives?'

The SIFT method maintains that when intuitive types hear a passage of scripture, they want to know how that passage will fire their imagination and stimulate their ideas. They tend to focus not on the literal meaning of what is being said, but on the possibilities and challenges implied. Intuitive types may want to explore all of the possible directions in which the passage could lead. They welcome preachers who throw out suggestions and brain storm possibilities, whether or not these are obviously linked to the passage, and whether or not these ideas are followed through. Intuitive types quickly become bored with too much detail, too many facts and too much repetition.

The third step in the SIFT method is to address the feeling perspective. It is the feeling perspective which examines the human interest in the biblical text and learns the lessons of God for harmonious and compassionate living. The third set of questions asks, 'How does this passage speak to the feeling function? What is there to speak about fundamental human values, about the relationships between people, and about what it is to be truly human?'

The SIFT method maintains that when feeling types hear a passage of scripture, they want to know what the passage says about personal values and about human relationships. They empathise deeply with people in the story and with the human drama in the narrative. Feeling types are keen to explore the lives of people about whom they hear in scripture. They want to explore what it felt like to be there at the time and how those feelings help to illuminate their Christian journey today. They welcome preachers who take time to develop the human dimension of the passage and who apply the passage to issues of compassion, harmony, and trust. Feeling types quickly lose interest in theological debates which explore abstract issues without clear application to personal relationships.

The fourth step in the SIFT method is to address the thinking perspective. It is the thinking perspective which examines the theological interest in the biblical text and which reflects rationally and critically on issues of principle. The fourth set of questions asks, 'How does this passage speak to the thinking function? What is there to speak to the mind, to challenge us on issues of truth and justice, and to provoke profound theological thinking?'

The SIFT method maintains that when thinking types hear a passage of scripture, they want to know what the passage says about principles of truth and justice. They become caught up with the principles involved in the story and with the various kinds of claims about truth being made. Thinking types are often keen to learn theology and to follow through the implications and the logic of the positions they adopt. Some thinkers apply this perspective to a literal interpretation of scripture, whilst other thinkers are more at home with the 
liberal interpretation of scripture. They welcome preachers who are fully alert to the logical and to the theological implications of their themes. They value sermons which debate fundamental issues of integrity and righteousness. Thinking types quickly lose interest in sermons which concentrate on applications to personal relationships, but fail to debate critically issues of theology and morality.

The theoretical bases, of the SIFT method of biblical hermeneutics and liturgical preaching, generate hypotheses that can be tested empirically by the two main research perspectives developed within empirical theology, following quantitative and qualitative traditions (see Francis, Robbins \& Astley 2009). To date three studies have been reported in the quantitative tradition by Village and Francis (2005), Francis, Robins and Village (2009), and Village (2010), and four studies have been reported in the qualitative tradition by Francis (2010, in press a, in press b), and Francis and Jones (2011).

Within the quantitative tradition, Village and Francis (2005) and Village (2010) invited samples of 404 lay adult Anglicans and 718 recently ordained Anglican clergy respectively, to read a healing story from Mark's Gospel and then to choose between pairs of interpretive statements designed to appeal to particular psychological type preferences. The data demonstrated that preferences for interpretation were significantly correlated with psychological type preferences in both the perceiving process and in the judging process. Francis, Robbins and Village (2009) invited a sample of 389 experienced preachers to read Mark 1:29-39 and to record their evaluations of four reflections on this passage proposed by Francis (1997). The data demonstrated that preachers were four times more likely to prefer a sensing interpretation of the text rather than a thinking interpretation, emphasising the richness of the narrative rather than facing the theological questions posed by it. This reflected the ratio of dominant sensing types to dominant thinking types within the sample.

Within the qualitative tradition, all four studies followed the same basic procedure of inviting participants to work in type-alike groups to reflect on a specific passage of scripture and to identify their preferred approach to preaching on the passage. Francis (2010) invited two groups of Anglican preachers (24 licensed readers in England and 22 licensed clergy in Northern Ireland) to study the Marcan narrative concerning the five loaves and two fishes (Mk 6:34-44). Francis (in press a) invited three groups (31 Anglican clergy in England, 14 Anglican clergy and licensed readers in England, and a mixed group of 47 clergy and lay people) to study the Marcan narrative concerning the cleansing of the temple and the cursing of the fig tree (Mk 11:11-21). Francis and Jones (2011) invited two groups (26 ministry training candidates and 21 Anglican clergy and readers in England) to study the resurrection narratives from Mark 16:1-8 and from Matthew 28:1-15. Francis (in press b) invited one group (21 Anglican clergy and readers in England) to study the Johannine foot washing narrative (Jn 13:26-15). Each of these four qualitative studies has enriched appreciation of the ways in which the distinctive voices of sensing, intuition, feeling, and thinking interpret and reflect on sacred text.

The four qualitative studies reported by Francis (2010, in press a, in press b) and Francis and Jones (2011) have established a research tradition that deserves extension to other groups of participants and to other passages of scripture. Against this background, the aim of the present study is to build on this tradition, amongst two groups of Anglican ministry training candidates, by drawing on the Johannine feeding narrative (Jn 6:4-22).

\section{Method \\ Procedure}

In the context of a residential programme, the participants were invited to complete a recognised measure of psychological type and to experience working in groups structured on the basis of psychological type theory. Reading, reflecting on and proclaiming scripture was an integral part of the group experience.

\section{Measure}

Psychological type was assessed by the 126-item Form G (Anglicised) of the Myers-Briggs Type Indicator (Myers \& McCaulley 1985). This instrument uses a force-choice questionnaire format to indicate preferences between extraversion or introversion, sensing or intuition, thinking or feeling, and judging or perceiving. Broad support for the reliability and validity of the instrument is provided in the international literature as summarised by Francis and Jones (1999), who additionally demonstrated the stability of the scale properties of the instrument amongst a sample of 429 adult churchgoers. In another study amongst 863 Anglican clergy, Francis et al. (2007) reported the following alpha coefficients: extraversion, .80; introversion, .79; sensing, .87; intuition, .82; thinking, .79; feeling, .72; judging, .85; perceiving, .86 .

\section{Study one: Results Participants}

A total of 19 Anglican ministry training candidates (training for ordained local ministry, reader ministry, and other lay ministries) participated in the weekend residential programme (6 men and 13 women). The results of the MyersBriggs Type Indicator described a group characterised by preference for introversion (14) over extraversion (5), for intuition (13) over sensing (6), for feeling (12) over thinking (7), and for judging (12) over perceiving (7). In terms of the 16 complete types, the most frequently occurring type was INFJ (introversion, intuition, feeling, and judging), with 4 participants within this category. In terms of dominant types, there were 9 dominant intuitive types, 6 dominant sensing types, 2 dominant feeling types, and 2 dominant thinking types. 


\section{The perceiving process}

On the basis of their reported perceiving preferences, the participants were divided into three groups: one group comprising the highest scoring sensing types, one group comprising the highest scoring intuitive types, and a third group drawing together lower scoring sensing types with lower scoring intuitive types (therefore mainly intuitive). The three groups were asked to read John 6:4-13 (the Johannine feeding narrative) and to accomplish three tasks: to reflect on the passage, to note the issues of interest to them, and to prepare material for preaching. In the following analysis attention will be given to the group of sensing types and the group of intuitive types.

\section{Sensing}

The sensing group began their presentation by drawing attention to the method that they adopted for dealing with the task. They had approached the passage by reading the verses sequentially, by noting the themes as they emerged through the text, and by drawing preaching implications from each of the noted themes in turn for their preaching. Seven themes emerged from the ten verses and were noted in a clear listing.

First, they noted that Jesus had seen and identified the need pressing on the people. They were hungry (v. 5). We, too, need to be aware of the needs amongst the people to whom we are preaching.

Second, they noted that Jesus knew the solution to the problem (v. 6) and tried to open the eyes of others to the solution. We, too, need to allow God to open our eyes to the solution to the needs of the people around us.

Third, they noted that Jesus challenged Philip, but that Philip did not have an answer (v. 7). We, too, need to be challenged, even when we do not have the answer.

Fourth, they noted that Andrew spotted a potential answer when he saw the boy who had five barley loaves, but Andrew had no confidence in his solution (v. 8). We, too, need to check how confident we are in our responses.

Fifth, they noted how the multitude was fully fed with such a finite resource (v. 12). We, too, have limited resources, but must share confidence in God's use of our limited resources.

Sixth, Jesus took the loaves, gave thanks, and shared the loaves (v. 11). We need to recognise the abundance of God's love and of God's generosity. God has enough to feed us practically, physically and spiritually.

Seventh, they noted how twelve baskets were filled with the food left over. The twelve baskets remind us of the twelve tribes of Israel and of the twelve apostles.

The sensing group concluded their presentation by indentifying their main theme: God provides now and in the future.

\section{Intuition}

The intuitive group also began their presentation by drawing attention to the method that they adopted for dealing with the task. They had approached the passage by identifying three alliterative themes (all beginning with the letter ' $c$ ': compassion, creativity and communion) and the passage was then read through this interpretative lens. From that point a mind map was drawn to capture and to express a freeflowing stream of four creative ideas emerging at random from the passage, not all of which necessarily reflected the three identified themes.

The first creative idea tried to approach the whole narrative through the eyes of the boy who had the five barley loaves and two fishes. What did he feel about the way in which his food was taken from him and about how everything escalated from that very moment? In one sense, that boy had a very minor role in the story, and everything hinged upon him being there and being ready to give over his bread and his fishes.

The second creative idea tried to concentrate on the facts in the story: five loaves, five thousand people, twelve baskets. All of these facts point to the Kingdom of Heaven and to how, in the Kingdom of Heaven, our needs are met by Christ.

The third creative idea tried to capture the eucharistic teaching in the passage. Here is a narrative about the fellowship of communion when the five thousand people sat down together in one place. Here is a narrative about trust in God. The disciples trusted Jesus to deal with the crowd. The crowd trusted Jesus to feed them. We trust that God will supply our needs.

The fourth creative idea tried to expand on the key theme of 'feeding'. The feeding is even more than feeding within the fellowship of communion. The narrative symbolises God's commitment to meet our physical needs (food), our spiritual needs (teaching), and our other needs (diverse).

The intuitive group concluded their presentation by returning to and reiterating the three alliterative themes identified at the outset (compassion, creativity and communion), without feeling any need to demonstrate how these themes had been reflected within their free-flowing stream of creative ideas.

\section{The judging process}

On the basis of their reported judging preferences, the participants were divided into three groups: one group comprising the highest scoring thinking types, one group comprising the highest scoring feeling types, and a third group drawing together lower scoring thinking types and lower scoring feeling types (therefore mainly feeling). The three groups were then asked to read John 6:14-22 (the Johannine continuation of the feeding narrative) and to accomplish three tasks: to reflect on the passage, to note the issues raised by the passage, and to prepare material 
for preaching. In the following analysis, attention will be given to the group of feeling types and to the group of thinking types.

\section{Feeling}

The feeling group began their presentation by saying that it was rooted in a discussion of how different people in the narrative were feeling about what was going on. From this starting point a series of reflections emerged.

The first reflection stood in Jesus' shoes and reflected how Jesus took himself off to God in times of need, not allowing the crowd to manipulate God's will.

The second reflection stood in the disciples' shoes and reflected how Jesus met them at unexpected times and in unexpected places, and how Jesus was always there when needed, to reassure them. Occasions like this raised the disciples' awareness of, and appreciation for, the sense of awe and wonder that made the disciples' experience of Jesus so special.

The third reflection stood in the crowds' shoes. The crowd was very confused by Jesus, by who he was and by how he acted in relationship to them. One minute he was there and the next minute he was nowhere to be found. They were left searching for Jesus, wondering why he had left them, and why he had not allowed them to make him their king.

The fourth reflection tried to look back on the event with hindsight and with the benefit of knowledge of the resurrection. Had the disciples or the crowd known about the resurrection then, the events would have taken a very different turn.

The fifth reflection took us back to our own church life and to our own congregations. The crowd and the disciples experienced Jesus in very different ways and had shaped very different expectations of Jesus. We need to appreciate where people are coming from today in their response to Jesus.

The feeling group concluded without trying to draw these different strands together.

\section{Thinking}

The thinking group structured their presentation through posing three analytical questions and by proposing responses to those questions.

The first question was: Who is Jesus? They addressed this question through the lens of two distinct groups of individuals shaping the narrative. Through the eyes of the disciples, Jesus was seen as a divine, mysterious and Godlike king; as a king who can never be controlled by them; as a king who came and went as he pleased. Through the eyes of the crowd, Jesus was seen as a powerful king; as a king whom they could control to serve their own agenda. Their agenda may have been both economic (Jesus fed them) and political (Jesus could liberate them).

The second question was: What did people want of Jesus? Again they addressed their question from two perspectives: through the lens of the crowd and through the lens of the disciples. The crowd clearly wanted to take Jesus by force and to crown him as their leader. The disciples' agenda was less clearly set out. It is obvious that they wanted Jesus with them, but it is less obvious why they wanted him. What kind of agenda did the disciples have? What is clear is that, after this event, Jesus moved toward the disciples and away from the crowd.

The third question was: Are we putting Jesus into a box of our own making? Having seen so clearly how the crowd and how the disciples had such different expectations of Jesus, we are challenged to test our expectations. Are we properly aligned with the disciples' commitment to let Jesus lead them? Are we willing to invite Jesus in and to take the risk of Jesus' unpredictability and taking us where he wants us to go? Do we take away from the narrative a view not just of the power of Jesus, but of the mystery as well?

The thinking group left the presentation right there with the challenging questions and the ongoing invitation to respond to those questions.

\section{Study two: Results Participants}

A small group of seven candidates, training for ordained or lay ministries in the Anglican Church, participated in a fourday residential programme ( 2 women and 5 men). The results of the Myers-Brigg Type Indicator identified 4 introverts and 3 extraverts, 3 sensing types and 4 intuitive types, 5 feeling types and 2 thinking types, 4 judging types and 3 perceiving types. In terms of the 16 complete types, there were 2 ISTJs (introversion, sensing, thinking, and judging), 1 ESTJ (extraversion, sensing, thinking, and judging), 1 INTJ (introversion, intuition, thinking, and judging), 1 INFP (introversion, intuition, feeling, and perceiving), and 2 ENFPs (extraversion, intuition, feeling, and perceiving). In terms of dominant types there were 2 dominant sensing types, 3 dominant intuitive types, 1 dominant feeling type and 1 dominant thinking type.

\section{The perceiving process}

On the basis of their reported perceiving preferences, the participants were divided into three groups: one group comprising the two high scoring sensing types, one group comprising the two high scoring intuitive types, and the third group comprising one low scoring sensing type and two low scoring intuitive types. The three groups were asked to read John 6:4-13 (the Johannine feeding narrative) and to accomplish three tasks: to reflect on the passage, to note the issues of interest to them, and to prepare material for preaching. In the following analysis, attention will be given to the group of sensing types and to the group of intuitive types. 


\section{Sensing}

One member of the sensing group explained her approach to dealing with the passage. Firstly, she read the passage. Secondly, she closed her eyes and went through the steps of the story. She saw the huge crowd. She felt the hunger of the people. She experienced the anxiety that overwhelmed the disciples as they were overwhelmed by the needs of the people. She looked into the eyes of the boy who had the five barley loaves and two fish and saw his hopefulness that these could be of some use to Jesus. She saw the people sit down on the grass. She watched Jesus take the bread. She saw the people being fed and she saw the twelve baskets filled with the leftovers.

Next, when attempting to understand the facts of the matter correctly, the sensing group tried to work out whether this story was really about a miracle or about an example of sharing inspired by the boy's example.

Next, the sensing group identified, listed and numbered seven issues of interest to them from the passages:

- They considered Jesus' way of dealing with the disciples. Jesus set Philip the question to test him, although Jesus knew full well what he planned to do.

- They considered how the people were made to sit down. Here was an effective lesson in crowd control. There was no risk of a shambles.

- They considered how an assessment was made of the available resources. It all began with one boy and a small offering.

- They considered the example of the young boy inspiring others to share what they had brought with them.

- They considered the number of baskets filled with the leftovers. They saw that 12 baskets represented one for each of the disciples.

- They considered the disciples' anxiety that they did not have enough food to meet the peoples' needs; and they noted Jesus' confidence that there would be enough.

- They considered how the people needed to be able to witness this great event before they could believe.

From their description of and reflection on the narrative, the sensing group identified their key theme for the sermon. The theme is that in this narrative Jesus set the example that we must follow. Share what you have received and God will increase it. Knowing what God can do with our inadequate offering really encourages us to place it in God's hands.

This group returned late, feeling that it had left the task only half complete. There was so much more detail to examine that this group returned frustrated with the lack of adequate time allowed for the task.

\section{Intuition}

The intuitive group approached the passage directly by identifying one theme around which they could organise their appreciation of the issues and from which they could prepare their sermon. The theme, they said, is about trust in Jesus. Jesus tested the disciples by challenging them to solve the problem of the hunger of the people. The disciples so clearly failed to display the trust that Jesus expected from them. They simply could not rise to the challenge.

In stark contrast with the disciples who had been with Jesus so long, a young boy stood out from the crowd and brought to Jesus all that he had. That young boy trusted Jesus to be able to do something with what he had to offer.

What that young boy had to offer was really ridiculous. It was totally inadequate for the needs of the crowd and it would have made better sense for him to keep it for the needs of his own family.

Yet in doing what he did, the young boy displayed a trust in Jesus that his disciples lacked. The young boy offered what seems to be so obviously inadequate with complete trust. Then Jesus uses what the boy offers in ways that were beyond the imagination of the disciples.

Jesus increased that small offering to such an extent that 12 baskets were left over. The lesson is that whatever we have to offer, however small, offering to Jesus will increase it beyond our imagination.

Having pursued this approach through the passage, the intuitive group felt that they had performed all that could be carried out with the passage. This group came back early, feeling bored and a little restless with the time allocated for the task.

\section{The judging process}

On the basis of their reported judging preference, the participants were divided into two groups: one group comprising the three thinking types and the other group comprising the four feeling types. The two groups were then asked to read John 6:14-22 (the Johannine continuation of the feeding narrative) and to accomplish three tasks: to reflect on the passage, to note the issues raised by the passage, and to prepare material for preaching. In the following analysis, attention will be given to both groups.

\section{Feeling}

The feeling group approached the passage by reviewing the narrative from the perspective of the characters. They were concerned to access the motivation underlying the human actions.

Firstly, they pondered on Jesus' motivation for withdrawing from the crowd. Jesus, they surmised, did not want to be made an earthly king; he wanted to bring peace as a heavenly king.

Secondly, they pondered on the disciples' experiences in the boat. They were in the dark both literally, because it was night time, and metaphorically, because they had no real 
insight into what was going on. They were terrified, as a strong wind was blowing and the lake became rough. Then they saw Jesus walking on the lake and their fear turned into terror.

When Jesus spoke to the disciples, his message was one of calm: 'Do not be afraid', he said. Jesus reassured the disciples and their world was safe again, and they reached dry land.

When the disciples saw Jesus walking on the water, they recognised him and recognised who he really was. Jesus' presence overcame their fear.

The disciples particularly wanted to take Jesus into their boat. They wanted Jesus there with them. But that is not how it actually is. Jesus needs to set them up to row their own boat. Jesus needs to enable them to work things out for themselves, knowing that he will not be physically present forever.

Having viewed the narrative, firstly from the perspective of Jesus, and secondly from the perspective of the disciples, the feeling group thirdly viewed the narrative from the perspective of the crowd. What impressed the group now was the way in which the crowd thought that they knew what was going on, but had in fact misunderstood it. They saw that Jesus had not got into the boat with the disciples and they assumed that the disciples had gone away alone. The truth of the matter is that Jesus is never far from the disciples at any time. Jesus comes up to the boat when he is most needed.

From this reflection on the narrative the feeling group identified their theme for preaching as follows: Although Jesus does not do everything for us, he is always there for us whatever happens.

\section{Thinking}

The thinking group approached the passage by analysing out the issues raised and listing them as simple bullet points:

- Jesus rejected popularist kingship.

- The thinking response of Jesus was designed to take the emotion out of the situation. He withdrew strategically.

- Jesus' withdrawal also provided the necessary time for detached introverted reflection on the situation.

- The passage shows that Jesus was in control of the situation because he could figure out where things were going and what they could lead to.

- The disciples may have been baffled and disappointed by Jesus' way of dealing with things. The great feeding could have led directly to enthronement. They would have achieved their goal.

- In face of this disappointment, the disciples reverted back to their roots. They were back in their boat and Jesus was left standing on the shore.

- In spite of being fishermen, the disciples shared the deeprooted Jewish loathing of the seas. The sea was the place of chaos and the home of evil.
- Without Jesus in the boat, the disciples ignored the objective, as their faith faltered and they could only sense that Jesus was far away from them.

- At the end of the passage (v. 21) the disciples still failed to grasp what was really going on. They wanted to get Jesus into the boat, whereas Jesus wanted to get them to dry land.

- Overall the passage is a passage of stark contrasts. The day starts on the sun-lit hillside in an oasis of flourishing grass. The day ends amid the dark stormy night on the lake in the turmoil of the wind and the waves.

Whilst the feeling group identified as their preaching theme the affirming message that Jesus is always there for us, the thinking group followed their analysis by identifying a challenging preaching theme, that faith falters. Their theme was supported by two particular points of challenge.

The first of these challenges was directed to those professionally employed in ministry today. In the narrative the disciples were the professionals, and their faith faltered when the seas grew rough. So we cannot assume that we (the professional preachers) can always model secure faith. Sometimes we need to recognise that the congregation arrives there first.

The second of their challenges pointed to the experiences of Christian disciples today, more generally. Here Jesus' disciples experienced a 'cold feet' moment. They were in a dark place. They had failed to understand what Jesus was doing and felt that Jesus had abandoned them to the stormy seas and to the deep waters.

Having posed the stark challenges, the thinking group did not leave the matter there. The gospel also offered a point of resolution when faith falters. Jesus does step into the abyss. Jesus does walk out across the stormy seas and through the dark night. Jesus does come to our rescue.

\section{Conclusion}

The present study drew on psychological type theory as introduced by Jung (1971), as operationalised through the Myer Myers-Brigg Type Indicator (Myers \& McCaulley 1985), and as extended to hermeneutical theory through the SIFT method of biblical hermeneutics and liturgical preaching (Francis \& Village 2008). This was in order to analyse the interpretations of the Johannine feeding narrative (Jn 6:4-22) advanced by two groups of Anglican ministry training candidates. Throughout the analysis the distinctive voices of the four psychological type functions could be detected.

In accordance with predictions from the theory, when preachers who held preference for sensing were placed together in a group, collectively they paid close attention to the text itself, savoured the details and sought out the practical application. When preachers who held preference for intuition were placed together in a group, collectively they sparked ideas in conversation with each other, looked for imaginative themes, and sought out possibilities for 
future development. When preachers who held preference for feeling were placed together in a group, collectively they focused their concern on the people in the narrative, on the human values, and on the connections between human life and relationships today. When preachers who held preference for thinking were placed together in a group, collectively they focused their concern on the issues raised by the narrative and on the broader theological principles involved.

The present study belongs to a wider research programme that has applied the same research method to other passages of scripture, including the Marcan feeding narrative (Mk 6:34-44) reported by Francis (2010). The Marcan narrative concerns the cleansing of the temple and the cursing of the fig tree (Mk 11:11-21) reported by Francis (in press a), the resurrection narratives from Mark 16:1-8 and from Matthew 28:1-15 reported by Francis and Jones (2011), and the Johannine footwashing narrative (Jn 13:2b-15) reported by Francis (in press b). Taken together these four earlier studies and the present study confirm the value of taking psychological type theory seriously within the contents of hermeneutics and homiletics.

From a practical perspective, preachers may be well advised to appreciate the extent to which their unconscious psychological type preferences may shape the way in which they proclaim scripture from the pulpit. Such selfawareness may also lead to a more realistic understanding of how this preaching is perceived by others. Within the perspective of Jungian psychological type theory, the individual preacher's dominant hermeneutical voice may fail to engage some members of the congregation, or even go so far as to alienate them. For dominant intuitive types in the congregation, the sensing type sermon may appear to be dull and unimaginative, and it may fail to keep their attention. For dominant sensing types in the congregation, the intuitive type sermon may appear to be disconnected from the text and impossible to pin down, and it may fail to engage their attention. For dominant feeling types in the congregation, the thinking type sermon may appear to be cold and analytic, and it may fail to engage their hearts. For the dominant thinking types in the congregation, the feeling type sermon may appear to avoid the issues of real concern, and it may fail to engage their heads.

From a theoretical perspective, it is necessary to examine the implications of these empirical findings for hermeneutical theory. If different readers (shaped by different psychological type preferences) read the sacred text in different ways, gain different insights from the narrative, and form different perspectives on the divine revelation, perhaps the full and rounded appreciation of the conversation between the Word of God (Bible) and the People of God (Church) needs to be informed by the careful and systematic integration of these different reader perspectives. Starting from the empirical observation that people differ in systematic ways (the psychology of individual differences) and from the empirical observation that hermeneutical perspectives are linked to such individual differences in psychological type, the SIFT method of biblical hermeneutics and liturgical preaching proposes a systematic way through which such insights may be integrated, and through which the People of God may hear more fully the Word of God.

\section{Acknowledgements Competing interests}

The author declares that he has no financial or personal relationship(s) which may have inappropriately influenced him in writing this article.

\section{References}

Francis, L.J., 1997, Personality type and scripture: Exploring Marks' Gospel, Mowbray, London.

Francis, L.J., 2005, Faith and psychology: Personality, religion and the individual, Darton, Longman and Todd, London.

Francis, L.J., 2010, 'Five loaves and two fishes: An empirical study in psychological type and biblical hermeneutics among Anglican preachers', HTS Theological Studies 66(1), Art. \#811, 5 pages. http://dx.doi.org/10.4102/hts.v66i1.811

Francis, L.J., (in press a), 'What happened to the fig tree? An empirical study in psychological type and biblical hermeneutics'.

Francis, L.J., (in press b), 'The Johannine footwashing and diaconal ordination: Practice interpretation and the SIFT method of biblical hermeneutics'.

Francis, L.J. \& Atkins, P., 2000, Exploring Luke's Gospel: A guide to the gospel readings in the Revised Common Lectionary, Mowbray, London.

Francis, L.J. \& Atkins, P., 2001, Exploring Matthew's Gospel: A guide to the gospel readings in the Revised Common Lectionary, Mowbray, London.

Francis, L.J. \& Atkins, P., 2002, Exploring Mark's Gospel: An aid for readers and preachers using year $B$ of the Revised Common Lectionary, Continuum, London.

Francis, L.J., Craig, C.L., Whinney, M., Tilley, D. \& Slater, P., 2007, 'Psychological profiling of Anglican clergy in England: Employing Jungian typology to interpret diversity, strengths, and potential weaknesses in ministry', International Journal of Practical Theology 11, 266-284. http://dx.doi.org/10.1515/IJPT.2007.17

Francis, L.J. \& Jones, S.H., 1999, 'The scale properties of the MBTI Form G (Anglicised) among adult churchgoers', Pastoral Sciences 18, 107-126.

Francis, L.J. \& Jones, S.H., 2011, 'Reading and proclaiming the resurrection: An

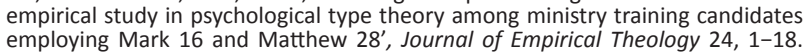
employing Mark 16 and Matthew 28', Journal
http://dx.doi.org/10.1163/157092511X571141

Francis, L.J., Robbins, M. \& Astley, J. (eds.), 2009, Empirical theology in texts and tables: Qualitative, quantitative and comparative perspectives, Brill, Leiden.

Francis, L.J., Robbins, M. \& Village, A., 2009, 'Psychological type and the pulpit: An empirical enquiry concerning preachers and the SIFT method of biblical hermeneutics', HTS Theological Studies 65(1), Art. \#161, 7 pages. http://dx.doi. org/10.4102/hts.v65i1.161

Francis, L.J. \& Village, A., 2008, Preaching with all our souls: A study in hermeneutics and psychological type, Continuum, London.

Jung, C.G., 1971, Psychological types: The collected works, vol. 6, Routledge and Kegan Paul, London.

Keirsey, D. \& Bates, M., 1978, Please understand me, Prometheus Nemesis, Del Mar, CA.

Myers, I.B. \& McCaulley, M.H., 1985, Manual: A guide to the development and use of the Myers-Briggs Type Indicator, Consulting Psychologists Press, Palo Alto, CA.

Village, A., 2010, 'Psychological type and biblical interpretation among Anglican clergy in the UK', Journal of Empirical Theology 23, 179-200. http://dx.doi. org/10.1163/157092510X527349

Village, A. \& Francis, L.J., 2005, 'The relationship of psychological type preferences to biblical interpretation', Journal of Empirical Theology 18, 74-89. http://dx.doi. org/10.1163/1570925054048929 


\section{Appendix}

John 6:4-22

${ }^{4}$ Now the Passover, the festival of the Jews, was near. ${ }^{5}$ When he looked up and saw a large crowd coming towards him, Jesus said to Philip, 'Where are we to buy bread for these people to eat?' ${ }^{6} \mathrm{He}$ said this to test him, for he himself knew what he was going to do. 'Philip answered him, 'Six months' wages would not buy enough bread for each of them to get a little.' ${ }^{8}$ One of his disciples, Andrew, Simon Peter's brother, said to him, ${ }^{9}$ There is a boy here who has five barley loaves and two fish. But what are they among so many people?' ${ }^{10} J$ esus said, 'Make the people sit down.' Now there was a great deal of grass in the place; so they sat down, about five thousand in all. ${ }^{11}$ Then Jesus took the loaves, and when he had given thanks, he distributed them to those who were seated; so also the fish, as much as they wanted. ${ }^{12}$ When they were satisfied, he told his disciples, 'Gather up the fragments left over, so that nothing may be lost.' ${ }^{13}$ So they gathered them up, and from the fragments of the five barley loaves, left by those who had eaten, they filled twelve baskets. ${ }^{14}$ When the people saw the sign that he had done, they began to say, 'This is indeed the prophet who is to come into the world.'
${ }^{15}$ When Jesus realized that they were about to come and take him by force to make him king, he withdrew again to the mountain by himself.

${ }^{16}$ When evening came, his disciples went down to the lake, ${ }^{17}$ got into a boat, and started across the lake to Capernaum. It was now dark, and Jesus had not yet come to them. ${ }^{18}$ The lake became rough because a strong wind was blowing. ${ }^{19}$ When they had rowed about three or four miles, they saw Jesus walking on the lake and coming near the boat, and they were terrified. ${ }^{20}$ But he said to them, 'It is I; do not be afraid. ${ }^{21}$ Then they wanted to take him into the boat, and immediately the boat reached the land towards which they were going.

${ }^{22}$ The next day the crowd that had stayed on the other side of the lake saw that there had been only one boat there. They also saw that Jesus had not got into the boat with his disciples, but that his disciples had gone away alone.

New Revised Standard Version Bible, copyright 1989, Division of Christian Education of the National Council of the Churches of Christ in the United States of America. Used by permission. All rights reserved. 